\title{
Construction and Validation of the Brazilian Questionário de Respostas Socialmente Habilidosas Segundo Relato de Professores (QRSH-PR)
}

\author{
Alessandra Turini Bolsoni-Silva1, Edna Maria Marturano², and Sonia Regina Loureiro² \\ ${ }^{1}$ Universidade Estadual Paulista (Brazil) \\ ${ }^{2}$ Universidade de São Paulo (Brazil)
}

\begin{abstract}
Behavioral problems in preschool children are one of the most frequent motives for seeking psychological care by parents and caregivers. Instruments are considered necessary, created from a Social Skills Training theoretical-practical perspective, which may systematically assist the identification of social skills and behavioral deficits, helping professionals in the prevention and/or reduction of behavioral problems. The purpose of this study was to test the psychometric validity and reliability of an instrument for evaluation of Socially Skilled Responses, from a teacher's perspective (QRSH-PR). For this purpose, 260 preschool children were evaluated, differentiated in subgroups without and without behavioral difficulties, based on the Child Behavior Scale (Escala de Comportamento Infantil/ECI-Professor). Studies were conducted for construct, discrimination, concurrent and predictive validity. The Cronbach Alpha was calculated to evaluate internal consistency. The obtained results pointed to positive indicators in reference to construct, discrimination, and predictive validity, and even for good internal consistency, indicating that the items consistently measure the construct of social skills, and differentiated children with and without behavioral problems. The questionnaire is considered to be gauged for evaluation of socially skilled responses from preschool children, and applicable in educational and clinical environments.
\end{abstract}

Keywords: validation, questionnaire, social skills, QRSH-PR

Los problemas conductuales en niños de preescolar son uno de los motivos más frecuentes de consulta psicológica por parte de padres y cuidadores. Se consideran necesarios instrumentos, construidos desde la perspectiva teórico-práctica del entrenamiento en habilidades sociales, que puedan contribuir sistemáticamente a la identificación de habilidades sociales y déficits conductuales, auxiliando a los profesionales en la prevención y/o reducción de los problemas de conducta. El propósito de este estudio fue probar la fiabilidad y validez de un instrumento para la evaluación de las respuestas de habilidad social, desde la perspectiva del profesor (QRSH-PR). A este fin, se evaluó a 260 preescolares, divididos en subgrupos con y sin dificultades de conducta, basándose en el Infantile Behavior Scale (Escala de Comportamento Infantil/ECl-Professor). Se realizaron estudios de validez de constructo, discriminación, competición y predicción. Se calculó el coeficiente Alfa de Cronbach para evaluar la consistencia interna. Los resultados apuntan a indicadores positivos en cuanto a la validez de constructo, discriminación, validez predictiva y buena consistencia interna, indicando que los ítems miden consistentemente el constructo de habilidades sociales y diferencian niños con y sin problemas de conducta. Se considera que el cuestionario es indicado para la evaluación de las respuestas de habilidad social de preescolares, y aplicable en contextos clínicos y educativos.

Palabras clave: validación, cuestionario, habilidades sociales, QRSH-RP

Correspondence concerning this article should be addressed to Alessandra Turini Bolsoni-Silva. Av. Eng Luiz Edmundo C. Coube, s/n. Vargem. Limpa - Cep.: 17015-970. - Bauru - S.P. Brazil. E-mail: bolsoni@fc.unesp.br

How to cite the authors of this article: Bolsoni-Silva, A.T., Marturano, E.M., Loureiro, S.R. 
The theoretical-practical field of Social Abilities Training describes various social skills to which the following categories refer: 1) social skills related to communication: ask and respond to questions; gratify and praise; request and give feedback in social relationships; begin, maintain, and terminate a conversation; 2) social skills of civility: say «please»; say «thank you» introduce oneself; give compliments; take one's leave; 3) assertive coping social skills: express an opinion, agree, disagree; give, accept, and refuse requests; ask forgiveness and admit faults; establish sexual/affectionate relationships; end a relationship; express anger and request behavioral changes; interact with authorities; deal with criticism; 4) empathic social skills: paraphrase, reflect feelings, and express support; 5) social skills related to work: coordinate a group; public speaking; resolve problems, make decisions, mediate conflicts; academic social skills; and 6) social skills related to expressing positive emotions: make friends; express solidarity and cultivate love (Del Prette \& Del Prette, 2001).

Caldarella and Merrell (1997), who seek to study social skills in children, indicate, through revision of the literature, a diversity of child social skills: 1) skills related to relationships with peers (give compliments, praise, offer help, invite peers to play, etc.); 2) self control skills (control mood, negotiate, deal with criticism, etc.); 3) academic skills (seek answers to questions, follow teacher's instructions, work independently, etc.); 4) adjustment skills (follow rules and instructions, use free time appropriately, attend to requests, etc.); 5) assertive skills (initiate conversation, accept invitations, respond to compliments, etc.) among others.

More recently, in respect to child social skills, Del Prette and Del Prette (2006) indicate the following social skills as fundamental to evaluate all of the child's social skills: self control and emotional expression, civility, empathy, assertiveness, solution of interpersonal problems, ability to make friends, and academic social skills.

Child social skills are understood as those that permit behavioral «cusps» (Bolsoni-Silva, 2003). The «cusps» are simple or complex changes that occur during the entire development of the child, and cause other anticipated changes, promoting the acquisition of new skills and further development (Rosales-Ruiz \& Baer, 1997).

It is possible that socially skilled behaviors may promote proper development and prevent the development of behavioral problems insofar as the they enable the child to interact more positively with their peers, teachers, and family, increasing the chance of receiving social reinforcement, such as attention and praise, in addition to resolving problems, without, overall, being aggressive, for example. In this line of reasoning, such behaviors may enable behavioral «cusps» (Rosales-Ruiz \& Baer, 1997), which, in respect to changes in the developmental process would be important for the individual or the species, since they would allow the child to come into contact with relevant contingencies for learning, whether social or academic. Such concepts may concur with social competence, insofar as it has an evaluative characters, suggesting that certain social skills, expressed in social interactions, may favor the amplification of reinforcement, and dampening of losses in interpersonal relations, in such manner as to resolve immediate problems and ameliorate future difficulties (Del Prette \& Del Prette, 1999). In this sense, the concept of social competence is functional, however, the known instruments measure social skills more than social competence.

According to a study conducted by the NICHD (National Institute of Child Health and Human Development Early Child Care Research Network, 2003), social skills evaluated by mothers and teacher in the early childhood education years are important predictors of later adjustment and quality of teacher-student relations. However, in the Brazilian context, resources are lacking for evaluation of social skills in preschool children (Del Prette \& Del Prette, 2006). An instrument (SMHSC-Del-Prette) was recently created to evaluate social skills in elementary school children (Del Prette \& Del Prette, 2006), which implies that the children evaluate their own performance.

Despite the literature being vast in respect to distortions in the judgment of teachers, some authors (Gerber \& Semmel, 1984; Gresham, 1996; Gresham, McMillan \& Bocian, 1997; Gresham, Reschly \& Carey, 1987) that work with this matter believe that the majority of teachers make precise judgments of performance and are open to corrective feedback.

Considering this lack of studies regarding the evaluations of psychometric properties of instruments that evaluate social skills in young children, this article proposes to contribute to the construction and validation of a questionnaire for evaluation of social skills in preschool children, with the following objectives: (a) to present the Questionnaire of Socially Skilled Responses, as reported by teachers ( Questionário de Respostas Socialmente Habilidosas, segundo relato de professores, or QRSH-PR), intended for children from five to seven years of age; (b) evaluate its internal consistency and construct, discrimination, competition, and predictive validity (Nunnally, 1970; Pasquali, 1997; 2000). The project is divided into two sections, the first being dedicated to presentation of the instrument, and the second to the psychometric studies.

\section{Development of the Instrument}

The principle that guided the drafting of the questionnaire was the relationship found, in the literature, between social skills and behavioral problems in preschool children, in which the greater the deficits in social skills, the greater the risk of developing behavioral problems (Caballo, 1997; Del Prette \& Del Prette, 2001; Ferreira \& Marturano, 2002). Considering the lack of instruments that evaluate social skills in preschool children, in the Brazilian context, an interest has arisen in conducting this study. 
The first step was to conduct a revision of the literature in order to obtain items predictive of social skills in children. We found few studies; among them, what had the most impact in the creation of the instrument was that of Caldarella and Merrell (1997), in addition to studies by Del Prette and Del Prette (1999), Caballo (1997), Hidalgo and Abarca (1992), McFall (1982). Based on the revision, we indentified a total of 27 items related to skills in interaction with the teacher and with peers, to be evaluated by the teacher regarding the child's behavior in the classroom. The yes/no model was adopted as far as the form of evaluation, for the occurrence or absence of a behavior, indicated by an «X» in front of the item.

To effect the calibration of the instruments, we conducted a pilot study, initially with 13 participants from a Municipal School of Early Childhood Education (Escola Municipal de Educação Infantil, EMEI) from the same city in which the data were later collected. In the evaluation of the participants, the instruments was clear in regard to instructions and the items.

In a second stage, the instrument was applied in the format mentioned above. Twenty two teachers were asked to indicate children that they believed had behavioral problems (indication of behavioral problem, or indicativo de problema de comportamento - IPC), and child more socially skilled (indication of socially skilled behavior, or indicativo de comportamento socialmente habilidoso - ICSH), including a total of 30 preschool children in each group, distributed in six Municipal Early Childhood Education School in a city within São Paulo. The questionnaire was applied to each child, as well as the Child Behavior Scale B from Rutter (IBS-PR), adapted by Santos (2002), which evaluated behavioral problems. The teachers responded to the instrument individually, answering the questions in writing, any question they being clarified upon request. In the comparison of the results from the IPC and ICSH groups, the group of children indicated by the teachers as having behavioral problems had an average score higher in 18 of the 26 items from the ECI-PR. On the other hand, the children indicated as being socially skilled has greater scores in 22 of the 24 items on the QRSH-PR.

Based on this pilot testing, the following alterations were implemented: (a) face to face application instead of the questionnaire is filled out by hand; (b) modification of the evaluation model from yes/no to a three point scale, in which evaluation of the occurrence of responses has three options: «not applicable», «somewhat applicable», and «definitely applicable», which were attributed values, respectively, of 0,1 , and 2. (c) removal of three items, which, despite being described in a different manner, expressed ideas already contained in other items: «becomes irritate or sad with minor difficulties», «expresses feelings of discomfort», «expresses feelings».

The pilot study allowed adjustment of the QRSH-PR, which, in the final version, was composed of 24 items
(Annex 1). Table 1 presents the items, as well as a corresponding trail with the classes of social abilities from the taxonomy proposed by Caldarella and Merrel (1997).

As observed in Table 1, QSRH-PR includes socially skilled responses referring to four among the five classes proposed by the authors: Relationship Skills (13 items), Assertive Skills (6 items), Academic Skills (3 items), and Self-Control Skills (2 items). The Adjustment Skills class is not represented in the instrument. One should note that the correspondence is only approximated, since the same socially skilled response, depending on the context and its functionality, may be assigned to more than one class; this is the case, for example, for giving compliments, praising others, asking questions.

We concluded that the methodological requirements appropriate to the drafting of the instrument were satisfied: The QRSH teacher version (QRSH-PR) was created from a clearly delimited theoretical reference; it was based on empirical research in the area of child social skills; its items were described in behavioral terms, guaranteeing the definition of the construct of the instrument; and, finally, the operationalization of the construct was given from a sufficient but not excessive number of items (Pasquali, 1999).

Table 1

Items from the QRSH-PR and their correspondence with social skills classes

\begin{tabular}{|c|c|}
\hline Social skill class & Item from the QRSH-PR \\
\hline R - Relationship skills & $\begin{array}{l}\text { brinca com colegas } \\
\text { comunica-se positivamente } \\
\text { cumprimenta } \\
\text { expressa carinhos } \\
\text { faz amigos } \\
\text { faz elogios } \\
\text { interage de forma não verbal } \\
\text { mostra interesse pelos outros } \\
\text { tem relações positivas } \\
\text { participa de grupos } \\
\text { participa de temas de discussão } \\
\text { presta ajuda } \\
\text { usualmente está de bom humor }\end{array}$ \\
\hline A - Assertive skills & $\begin{array}{l}\text { expressa direitos } \\
\text { expressa opiniões } \\
\text { não se deixa intimidar } \\
\text { negocia e convence outras pessoas } \\
\text { toma a palavra } \\
\text { toma iniciativa }\end{array}$ \\
\hline HA - Academic skills & $\begin{array}{l}\text { faz pedidos } \\
\text { faz perguntas } \\
\text { procura atenção }\end{array}$ \\
\hline AC - Self control skills & $\begin{array}{l}\text { expressa frustrações } \\
\text { expressa desejos }\end{array}$ \\
\hline
\end{tabular}




\section{Validation}

This section presents the analysis of construct, discrimination, concurrent, and predictive validity.

\section{Method}

\section{Participants}

The participants were recruited from 13 Municipal Early Childhood Education Schools (EMEI) in a city within the State of São Paulo, which were selected according to their location within the various geographical regions in the city. Sixty one teachers participated, who indicated 308 students with ages between five and seven years. From the total, 260 children participated in studies of internal consistency, validity of construct, and validity of discrimination, 130 with indications of behavioral problems, IPC (93 boys), and 130 with indications of socially skilled behaviors, ICSH (52 boys). The other 48 , together with their mothers, participated in a concurrent validity study, being 24 IPC (16 boys), and 24 ICSH (\& boys). There was indication of a significantly higher number of IPC boys, as much in the initial sample $\left(X^{2}=17,98\right)$ as in the concurrent validity study $\left(X^{2}=6.76\right.$; $\mathrm{p}<0,01)$.

\section{Procedure}

For composition of the sample of children, each teach was asked to indicate three students who, according to their perception, had socially skillful behaviors (ICSH Group), and three students that presented indications of behavioral problems (IPC Group). They were also asked to evaluate the behavior of students indicated as ICHS and IPC, according to the ECI-PR (Santos, 2002). The IPC group only maintained children with a score $\geq 9$ on the ECI-PR, being adjusted to the ICSH Group, in order to include the same number IPC and ICSH children for each teacher.

The teachers also responded to the Socially Skilled Responses Questionnaire for Teachers (QRSH-PR), object of the analysis of this present study. Mothers responded to the Socially Skills Responses Questionnaire for Parents, a version of the QRSH with 18 items corresponding to the items on the QRSH-PR (Bolsoni-Silva, Marturano, Pereira $\&$ Manfrinato, 2006). Six items are only present on the QRSH-PR: shows interest in others, has positive relationships, is not easily intimidated, participates in discussions, participates in play groups, and participates in discussions.

For verification of predictive validity, 62 children from the initial sample of 260 were reevaluated, after five years, including 28 children from the IPC Group (14 boys), and 34 from the ICSH Group (14 boys). In the reevaluation, all of the children were in the 5th grade of elementary school.
This study was conducted within the scope of the ethical standards required by the Helsinki Declaration, and by Resolution 196/96 of the National Health Council of Brazil. All participants in the study were previously informed of its objectives, the procedures, and the benefits of the study, and signed a Free and Clear Consent Form.

\section{Data Treatment}

Initially, a score corresponding to the frequency of a particular behavior was assigned for each of the response to the items on the instruments («definitely applies» - score 2; «applies a little»-score 1, and «does not apply»-score 0 . For the QRSH-PR, spreadsheets were created with the results from all of the times, as well as the total score. Analysis to obtain indicators of validity of construct, discrimination, concurrent, and predictive validity were processed, as well as the internal consistency of the instrument.

Validity of construct was determined by means of factorial analysis, conducted by the method of extraction of the principal components with Varimax rotation, after verification of the premises for this analysis (Pereira, 2004). To verify discrimination validity, the $\mathrm{T}$ Test was used in comparison of the IPC $(n=130)$ and ICSH $(n=130)$ groups in order to differentiate the instruments in reference to the groups with (IPC) and without (ICSH) behavioral problems.

Data acquired from the mothers on the QRSH-Parents were used for analysis of concurrent validity, in which the instrument was considered the «gold standard» for the QRSH-PR. To conduct the correlation analysis ( $\mathrm{r}$ coefficient for Pearson moment-product correlation), a spreadsheet was created containing the scores of the items common to the two instruments $(n=18)$ for each of the 48 participants (24 children with behavioral problems and 24 socially skilled children). To conduct the predictive validity analysis, Pearson correlation coefficients were calculated between the scores on the QRSH-PR acquired in both instances. preschool age and elementary school. A spreadsheet was created containing the scores per item and the total from the two instances for each of the 62 participants ( 28 children with behavioral problems and 34 socially skilled children).

Calculations were made using the SPSS statistical package. Results were considered statistically significant up to the value of $5 \%(\mathrm{p} \leq 0.05)$.

\section{Results}

Factorial Analysis. Despite the elevated internal consistency of the instrument (Cronbach alpha - 0.939), an analysis of the principal components was conducted to explore the adjacent factorial structure of the items in the QSRH-PR. In the verification of the premises of the factorial analysis, the factorability was considered 
satisfactory $(\mathrm{KMO}=0.939)$, and the hypothesis that the correlation matrix between the items is an identity matrix was rejected $(\mathrm{BTS}=3702.768, \mathrm{p}<0.0001)$. The criterion of a factorial load greater than 0.40 was established for inclusion of the items. Analysis of the principal components with varimax rotation and autovalues greater than 1 revealed four contributing factors to explain the $62.3 \%$ variance of the data. The factorial solution, including items with factorial loads and commonality, plus the number of items, the percentage of explained variance and the Cronbach Alpha coefficient for each component, is shown in Table 1. The table only includes factorial loads greater than 0.40. In the majority, the items acquired expressive loads only in one component, presenting low factorial loads in the others. Only four among the 24 items presented a factorial load greater than 0.40 in a second component, as can be seen in Table 2 .
The factorial loads between parentheses indicate that the item was not included in the calculation of internal consistency, having a higher load for another factor. The alpha coefficient, which corresponds to the consistency of each factor, was high for Factor 1 (0.92) and Factor 2 (0.87), and acceptable for Factor 3 (0.73). The behavioral/situational nature of social skills being taken as a presupposition, the examination of the content of the items with significant loads in each of the factors allowed their appointment and characterization as follows:

The first factor was appointed as Sociability and Emotional Expressiveness, by reflecting a tendency to positive approximation, friendliness and affection in relation to other persons, with appropriate expression of emotions. It includes 11 of the 13 items representative of Relationship Skills, as well as two items representative of Self Control Skills, as shown in Table 1 . The second factor was called «Social Initiative». Its

Table 2

Factorial matrix for the results of socially skilled response frequency on the QRSH-PR

\begin{tabular}{|c|c|c|c|c|c|c|}
\hline Items from the QRSH-RP & $\begin{array}{l}\text { HS* } \\
\text { Class }\end{array}$ & Factor 1 & Factor 2 & Factor 3 & Factor 4 & $h^{2}$ \\
\hline tem relações positivas & $\mathrm{R}$ & 0.774 & & & & 0.696 \\
\hline mostra interesse pelos outros & $\mathrm{R}$ & 0.754 & & & & 0.662 \\
\hline faz amigos & $\mathrm{R}$ & 0.733 & & & & 0.692 \\
\hline expressa frustração e desagrado de forma adequada & $\mathrm{AC}$ & 0.729 & & & & 0.549 \\
\hline comunica-se positivamente & $\mathrm{R}$ & 0.720 & & & & 0.646 \\
\hline expressa desejos & $\mathrm{AC}$ & 0.696 & & & & 0.640 \\
\hline expressa direitos & A & 0.689 & & & & 0.617 \\
\hline expressa carinhos & $\mathrm{R}$ & 0.667 & & & & 0.579 \\
\hline brinca com colegas & $\mathrm{R}$ & 0.628 & & & & 0.516 \\
\hline usualmente está de bom humor & $\mathrm{R}$ & 0.611 & & & & 0.522 \\
\hline faz elogios & $\mathrm{R}$ & 0.603 & $(0.484)$ & & & 0.677 \\
\hline cumprimenta & $\mathrm{R}$ & 0.595 & $(0.422)$ & & & 0.599 \\
\hline interage de forma não verbal & $\mathrm{R}$ & 0.576 & & & & 0.533 \\
\hline participa de grupos & $\mathrm{R}$ & 0.495 & & & & 0.364 \\
\hline toma a palavra & A & & 0.796 & & & 0.746 \\
\hline expressa opiniões & A & & 0.746 & & & 0.773 \\
\hline participa de temas de discussão & $\mathrm{R}$ & $(0.469)$ & 0.697 & & & 0.364 \\
\hline toma iniciativas & A & & 0.666 & & & 0.669 \\
\hline negocia e convence & A & & 0.653 & & & 0.547 \\
\hline presta ajuda & $\mathrm{R}$ & & 0.473 & & & 0.523 \\
\hline procura atenção & HA & & & 0.722 & & 0.582 \\
\hline faz pedidos & HA & & & 0.669 & & 0.586 \\
\hline faz perguntas & HA & & $(0.555)$ & 0.561 & & 0.724 \\
\hline não se deixa intimidar & A & & & & 0.863 & 0.796 \\
\hline eigenvalues & & 10.594 & 2.239 & 1.113 & 1.006 & \\
\hline Variance explained by the factor & & 28.992 & 18.824 & 9.805 & 4.680 & \\
\hline$\%$ of total accumulated variance & & 28.992 & 47.816 & 57.621 & 62.301 & \\
\hline Number of items with greater factorial weight in the factor & & 14 & 6 & 3 & 1 & \\
\hline Alpha coefficients & & 0.93 & 0.89 & 0.73 & - & \\
\hline
\end{tabular}

Note: $n=260$

*See Table 1 
items denote ease and flexibility in taking appropriate initiative in various social situations. Four out of the six items which compose it are representative of the Assertion class. The third factor was denominated Seeks Support, indicating attempts to obtain help, information, or attention, including all of the items on the QRSH-PR representative of Academic Skills. Factor 4, which only corresponds to one item, does not become intimidated, is difficult to interpret.

The presence of two factors with a low number of items (three and one, respectively) and the fact of having a the majority of items concentrated in the first factor indicates the need for new studies regarding this type of structure. On the other hand, the Sociability and Initiative factors apparently capture two conceptually significant and distinct social abilities. In the subsequent analysis of internal consistency and validity, only the items representative of these two factors were considered, the others being excluded.

Discriminating validity. Table 3 shows the results of the discriminating validity analysis. The results show that the instrument achieved good results in respect to discriminating validity, since, for the all twenty items, and for the total score, significant differences $(p=0.000)$ were found in the comparison between the IPC and ICSH groups. As such, the
QRSH-PR is able to differentiate between groups with and without behavioral problems in reference to the social skills.

Concurrent validity. Table 4 shows the results for concurrent validity, verifying that only three items were correlated in the comparison between the QRSH-PR and QRSH-Parents, being that of: communicates positively, makes friends and negotiates. Therefore, the QRSH-PR instrument, according to this analysis, shows low concurrent validity, however, one must consider that the family and academic environments may exhibit distinct skills in children, which may be the reason for the results obtained.

Predictive validity. Table 5 shows the results for predictive validity, indicating that nine of the 20 items were correlated significantly in the two evaluative measures (praises, is caring, makes friends, helps others, takes initiative in conversations, and expresses frustration). This list includes four of the six items of the Social Initiative factor. The total scores on the questionnaire obtained in both instances are also significantly correlated $(\mathrm{p}=0.002)$. Eleven items were not correlated in the two evaluations. As such, it was concluded that the instrument is sensitive in differentiating alternations in social skills over the pass of time.

Table 3

Discriminating validity: measurements, standard deviations, and results form the Test $t$ (2-tailed) compared with Groups IPC and ICSH

\begin{tabular}{|c|c|c|c|c|c|}
\hline \multirow{2}{*}{ Items from the QRSH-RP } & \multicolumn{2}{|c|}{ IPC } & \multicolumn{2}{|c|}{$\mathrm{ICSH}$} & \multirow{2}{*}{$\mathrm{t}$} \\
\hline & Measurement & D.P. & Measurement & D.P. & \\
\hline brinca com colegas & 1.68 & 0.56 & 1.95 & 0.27 & $-4.94 *$ \\
\hline comunica-se positivamente & 1.12 & 0.72 & 1.98 & 0.12 & $-13.33^{*}$ \\
\hline cumprimenta & 0.88 & 0.88 & 1.81 & 0.50 & $-10.48^{*}$ \\
\hline expressa carinhos & 0.95 & 0.83 & 1.92 & 0.30 & $-12.34 *$ \\
\hline faz amigos & 1.38 & 0.72 & 1.95 & 0.26 & $-8.37^{*}$ \\
\hline faz elogios & 0.58 & 0.77 & 1.62 & 0.67 & $-11.43^{*}$ \\
\hline interage de forma não verbal & 1.35 & 0.85 & 1.93 & 0.31 & $-7.36^{*}$ \\
\hline mostra interesse pelos outros & 0.81 & 0.75 & 1.75 & 0.55 & $-11.54 *$ \\
\hline tem relações positivas & 0.96 & 0.76 & 1.92 & 0.29 & $-13.42 *$ \\
\hline participa de grupos de jogos & 1.59 & 0.63 & 1.96 & 0.23 & $-6.27 *$ \\
\hline participa de temas de discussão & 0.75 & 0.83 & 1.82 & 0.46 & $-12.97 *$ \\
\hline presta ajuda & 1.11 & 0.82 & 1.79 & 0.54 & $-7.96^{*}$ \\
\hline usualmente está de bom humor & 1.37 & 0.72 & 1.98 & 0.20 & -9.19 \\
\hline expressa direitos & 0.85 & 0.75 & 1.89 & 0.36 & $-14.33^{*}$ \\
\hline expressa opiniões & 1.07 & 0.89 & 1.78 & 0.47 & $-8.01 *$ \\
\hline negocia e convence & 0.79 & 0.88 & 1.46 & 0.72 & -6.73 \\
\hline toma a palavra & 0.94 & 0.94 & 1.48 & 0.74 & $-5.21^{*}$ \\
\hline toma iniciativa & 1.14 & 0.90 & 1.78 & 0.51 & $-7.14^{*}$ \\
\hline expressa frustrações & 0.78 & 0.82 & 1.81 & 0.54 & $-11.88^{*}$ \\
\hline expressa desejos & 1.02 & 0.81 & 1.90 & 0.41 & $-10.99 *$ \\
\hline total & 21.13 & 9.17 & 36.53 & 4.41 & $-17.24 *$ \\
\hline
\end{tabular}

Note: $\mathrm{n}=260$

$* \mathrm{p} \leq 0.01$ 
Table 4

Concurrent validity: correlations between items and total scores from the QRSH-PR and the QRSH-Parents, averages, and standard deviation

\begin{tabular}{|c|c|c|c|c|c|}
\hline \multirow{2}{*}{ Items: QRSH-PR and QRSH-Parents } & \multirow{2}{*}{$\mathrm{r}$} & \multicolumn{2}{|c|}{ IPC } & \multicolumn{2}{|c|}{$\mathrm{ICSH}$} \\
\hline & & Measurement & D.P. & Measurement & D.P. \\
\hline brinca com colegas & 0.203 & 1.88 & 0.39 & 1.88 & 0.33 \\
\hline comunica-se positivamente & $0.436^{* *}$ & 1.63 & 0.61 & 1.79 & 0.50 \\
\hline cumprimenta & 0.021 & 1.38 & 0.84 & 1.58 & 0.61 \\
\hline expressa carinhos & 0.121 & 1.52 & 0.68 & 1.92 & 0.28 \\
\hline faz amigos & $0.659 * *$ & 1.71 & 0.62 & 1.75 & 0.60 \\
\hline faz elogios & -0.118 & 1.06 & 0.84 & 1.56 & 0.58 \\
\hline interage de forma não verbal & 0.004 & 1.60 & 0.71 & 1.69 & 0.47 \\
\hline presta ajuda & -0.021 & 1.58 & 0.71 & 1.43 & 0.71 \\
\hline usualmente está de bom humor & 0.123 & 1.69 & 0.62 & 1.73 & 0.54 \\
\hline expressa direitos & 0.050 & 1.35 & 0.79 & 1.52 & 0.62 \\
\hline expressa opiniões & -0.149 & 1.46 & 0.68 & 1.67 & 0.56 \\
\hline negocia e convence & $0.336^{*}$ & 1.06 & 0.84 & 1.40 & 0.82 \\
\hline toma iniciativa & -0.034 & 1.40 & 0.84 & 1.42 & 0.68 \\
\hline expressa desejos & 0.210 & 1.52 & 0.77 & 1.73 & 0.49 \\
\hline expressa frustrações & 0.049 & 1.27 & 0.89 & 1.69 & 0.51 \\
\hline total & 0.053 & 26.95 & 2.83 & 25.08 & 3.20 \\
\hline
\end{tabular}

Note: $\mathrm{n}=48$, being 24 IPC and 24 ICSH.

$r=$ Pearson Correlation Coefficient

$* \mathrm{p} \leq 0.05 ; * \mathrm{p} \leq 0.01$

Table 5

Predictive validity: Correlations between individual items and total scores from the QRSH-PR applied in early childhood education and in elementary education, averages, and standard deviations in the measurements obtained from two instances

\begin{tabular}{|c|c|c|c|c|c|}
\hline \multirow{2}{*}{ Items from QRSH-PR } & \multirow{2}{*}{$\mathrm{r}$} & \multicolumn{2}{|c|}{ Early Childhood Education } & \multicolumn{2}{|c|}{ Elementary Education } \\
\hline & & Measurement & D.P. & Measurement & D.P. \\
\hline brinca com colegas & 0.083 & 1.82 & 0.43 & 1.95 & 0.22 \\
\hline comunica-se positivamente & 0.159 & 1.58 & 0.67 & 1.74 & 0.51 \\
\hline cumprimenta & 0.019 & 1.44 & 0.82 & 1.45 & 0.84 \\
\hline expressa carinhos & $0.428 * *$ & 1.58 & 0.67 & 1.55 & 0.76 \\
\hline faz amigos & $0.322 *$ & 1.65 & 0.58 & 1.76 & 0.50 \\
\hline faz elogios & $0.266^{*}$ & 1.19 & 0.87 & 1.08 & 0.93 \\
\hline interage de forma não verbal & 0.037 & 1.65 & 0.70 & 1.73 & 0.61 \\
\hline mostra interesse pelos outros & 0.142 & 1.42 & 0.76 & 1.50 & 0.76 \\
\hline tem relações positivas & -0.045 & 1.71 & 0.61 & 1.44 & 0.78 \\
\hline participa de grupos & 0.162 & 1.81 & 0.47 & 1.90 & 0.39 \\
\hline participa de temas de discussão & $0.306^{*}$ & 1.23 & 0.88 & 1.40 & 0.88 \\
\hline presta ajuda & $0.444 * *$ & 1.47 & 0.74 & 1.55 & 0.58 \\
\hline usualmente está de bom humor & 0.085 & 1.74 & 0.54 & 1.73 & 0.58 \\
\hline expressa direitos & $0.353 * *$ & 1.45 & 0.76 & 1.60 & 0.69 \\
\hline expressa opiniões & $0.362 * *$ & 1.44 & 0.76 & 1.50 & 0.80 \\
\hline negocia e convence & 0.055 & 1.15 & 0.85 & 1.27 & 0.89 \\
\hline toma a palavra & $0.270 *$ & 1.16 & 0.93 & 1.11 & 0.91 \\
\hline toma iniciativa & 0.157 & 1.45 & 0.82 & 1.32 & 0.88 \\
\hline expressa frustrações & $0.311^{*}$ & 1.44 & 0.78 & 1.60 & 0.73 \\
\hline expressa desejos & 0.114 & 1.60 & 0.69 & 1.58 & 0.74 \\
\hline total & $0.386 * *$ & 29.79 & 10.75 & 31.03 & 8.79 \\
\hline
\end{tabular}

Note: $\mathrm{n}=62$, being 28 IPC and 34 ICSH.

$\mathrm{r}=$ Pearson Correlation Coefficient; $\mathrm{p}=$ significance level.

$* \mathrm{p} \leq 0.05 ; * * \mathrm{p} \leq 0.01$ 


\section{Discussion}

This investigation presents the QRSH-PR and the assessment of its psychometric qualities. It is an instrument for assessment of social skills in preschool children, by the teacher, intended for children from five to seven years of age. The methodological requirements for creation of instruments were met in its construction. The 24 items were derived empirically, being based on the taxonomy organized by Caldarella and Merrel (1997). With a high internal consistency, the instrument presents a factorial structure in which two conceptually significant factors cover, together, 20 items, and explain $48 \%$ of the variance in the results. The factors, called Relationship Skills and Social Initiative, correspond approximately to the classes Relationship Skills with Peers and Social Assertion from the taxonomy that served as the basis for construction of the QRSH-PR (Caldarella \& Merrel, 1997). Similar structure was found in the preschool version of the Social Skills Rating Scale - SSRS for teachers (Fantuzzo, Manz \& McDermott, 1998). In this study, the three factors identified were called by the authors «self control», «interpersonal skills», and «verbal assertion».

Low concurrent validity was observed, verifying that only three items were correlated in the comparison between the QRSH-PR and QRSH-parents instruments, the last being completed by the mothers. A low congruence between evaluation of social skills in preschool children by mothers and teachers was found, as well, by Fagan and Fantuzzo (1999) with the SSRS, preschool version. The notion may be supported that family and school environments are different, requiring different abilities from children, which could explain the low correlation between the measurements. Thus, the comparison between the evaluations by mothers and by teachers does not appear to be the ideal process for assessment of concurrent validity. A plausible alternative would be to compare the teachers' assessments with that of independent observers, which could be attempted in future research.

Predictive validity was noted for the total score on the questionnaire. A significant correlation was found between the evaluation made in early childhood education and a second evaluation, five years later. This is a result worthy of note, given the profound developmental changes that occur in the period between six and eleven years of age. In this phase, children experience two academic transitions, expand their cognitive abilities, and broaden their interpersonal relationships. The significant, positive correlation between the two evaluations indicates that individual variations in social skills, demonstrated early on, tend to persist in during the elementary education years. In particular, individual differences in some assertive abilities appear to persist, considering that in four of the six items on the QRSH-PR that compose the Social Initiative factor, a correlation was found between the evaluation conducted in early childhood education and that conducted in the 5th grade.
In the factorial analysis, the existence of four factors was verified. Two factors together respond for $47 \%$ of the factorial load with satisfactory indexes for internal consistency. It was possible to establish correspondence between the «Sociability and emotional expressiveness» factor, responsible for $29 \%$ of the factorial load, and the «Relationship skills» class in the taxonomy proposed by Caldarella and Merrel (1997). Likewise, the majority of the items representative of the «Social Initiative» factor, responsible for $18 \%$ of the factorial load, corresponds with the «Assertive skills» class from the same taxonomy.

It is notable that the «does not allow self to be intimidated», which appears in the fourth factor, may be classified as an assertive coping skill, however, the teachers did not respond in regard to this item in such manner as to include it in factor 2; this may have occurred because the item was likely interpreted as indicating aggression in the child, which is plausible, considering a tenuous threshold between aggression and assertion, and, in this case, the responses given were appropriate, since it would be an item indicating a behavioral problem, and not a social skill. We considerer that in a new version of the instrument, it will be necessary to formulate this item in such a manner as to avoid dubious interpretations. Additionally, in relation to the items in the third factor «seeks attention», «makes requests», and «asks questions», some hypotheses may be raised: It is possible that the teachers succeed in easily identifying children that seek too much attention, that are accustomed to receiving adjectives such as «cantankerous/ornery», and perhaps do not possess the same ability to identify those who seek attention in an appropriate manner, such as asking questions or making requests, which are skills that help in academic abilities, for example, asking to clarify academic questions, and also may indicate important social initiatives for obtaining attention and resolving problems.

The questionnaire also showed the capacity to differentiate child with or without behavioral problems (discriminating validity). Such a result has an impact for studies for evaluation and controlled clinical intervention, since it may be used in the evaluation of children with and without behavioral problems, as well as be applied in measures before and after intervention, verifying the acquisition, or failure thereof, of a set of social skills. In these studies, if the preschool child shows low indexes in the QRSH-PR, it is possible that they have a high score for behavioral problems, which may be verified with application of an instrument specifically for assessing behavioral problems, such as the ECI and/or the CBCL.

The predictive validity results show that the questionnaire is capable of verifying the persistence of skills over the passing of time, as well as the alteration thereof, being sensitive, and, thus, the effects of maturing (Nunnally, 1970) and changes environment. The correlative items in the two instances of application (preschool and elementary school) were "praises», «expresses opinions», "participates in discussion groups», «expresses rights», «is caring», «makes friends», «gives help», 
«takes verbal initiative», and «expresses frustration» indicating that children, despite experiencing moments of transition, maintain this set of social skills, reflecting on the correlation in the total score. Bolsoni-Silva (2003) found high scores in social skills in the preschool age, which was not maintained for 15 of the evaluated items, since they were not correlative in reference to elementary school; interesting that, despite being older children they presented a smaller set of social skills, which indicates the need for intervention in order to guarantee augmentation and maintenance of social skills.

The use of the questionnaire for socially skilled responses, teachers' version (QRSH-PR) becomes important, overall for the national reality, lacking instruments that evaluate social skills in preschool children, likely to be applicable in scientific, clinical and educational environments.

Its main limitation is in the reduced sample used especially in the studies for concurrent and predictive validity, suggesting the need for new studies in this direction in order to better assess the instrument. Another limitation is in the heterogeneous sample in reference to distribution by gender, in which there are statistically more boys than girls, demonstrating a tendency for occurrence of behavioral problems more in boys than in girls (Kaiser \& Hester, 1997). There is also a need for later studies that complement the validity of construct of the questionnaire, verifying how it performs in comparison with another external indicator, in such form as to note the representativity of the two theoretical dimensions identified in references to social skills (Sociability and Emotional Expressiveness and Social Initiative), and, from these empirical data, verify the need for inclusion of new items, which conceptually broaden comprehension of the construct.

In general, this study makes an instrument available to the scientific community that measures social skills in preschool children. The authors point out that this evaluation informs about the profile of social abilities, but it is insufficient for an evaluation of the reason that children behave thus in the school context. For this, it would be necessary to add other measures of evaluation, such as observation and interviews, in order to verify the situations where such abilities appear, as well as the consequences that maintain them in this environment.

\section{Referências}

Achenbach, T. M., \& Rescorla, L. A. (2000). Manual for the ASEBA Preschool Forms \& Proliles. Borlington, VT: University of Vermont, Research Center for Children, Youth, \& Family.

Artes, R., \& Barroso, L. P. (2000). Aspectos estatísticos da análise fatorial de escalas de avaliação. Em A. Gorenstein, L. H. S. G. Andrade, \& A. W. Zuardi (Eds.) Escalas de avaliação clínica em psiquiatria e psicofarmacologia (pp. 35-41). Sao Paulo: Lemos Editorial.

Bolsoni-Silva, A. T. (2003). Habilidades Sociais Educativas, variáveis contextuais e problemas de comportamento: comparando pais e mães de pré-escolares. Unpublished PhD. Dissertation. Ribeirão Preto: Universidade de São Paulo.

Bolsoni-Silva, A. T., Marturano, E. M., Figueiredo, V. A. P., \& Manfrinato, J. W. S. (2006). Habilidades sociais e problemas de comportamento de pré-escolares: Comparando avaliações de mães e de professoras. Psicologia: Reflexão e Crítica, v.19. (in press).

Bolsoni-Silva, A. T.; Del Prette, A., \& Oishi, J. (2003). Habilidades sociais de pais e problemas de comportamento de filhos. Revista Psicologia Argumento, 9, 11-29.

Bordin, I. A. S., Mari, J. J. \& Caeiro, M. F. (1995). Validação da versão brasileira do "Child Behavior Checklist" (CBCL) (Inventário de Comportamentos da Infância e Adolescência): dados preliminares. Revista ABP-APAL, 17 (2), 55-56.

Caballo, V. E. (1997). El papel de las habilidades sociales en el desarrollo de las relaciones interpersonales. In D. R. Zamignani (Ed.), Sobre comportamento e cognição (pp. 229-233). São Paulo: ARBytes Editora.

Caldarella, P., \& Merrell, K. W. (1997). Common dimensions of social skills of children and adolescents: A taxonomy of positive behaviors. School Psychology Review, 26 (2), 264-278.

Child Development, November/December 2003, Volume 74, Number 6, Pages 1639 - 1662.

Del Prette, Z. A. P., \& Del Prette, A. (1999). Psicologia das Habilidades Sociais: Terapia e educação. Petrópolis: Vozes.

Del Prette, Z. A. P., \& Del Prette, A. (2001). Psicología das relações interpessoais. Vivências para o trabalho em grupo. Petrópolis: Vozes.

Del Prette, Z. A. P., \& Del Prette, A. (2006). Psicologia das habilidades sociais na infância. Petrópolis: Vozes.

Fantuzzo, J. W., Manz, P. H., \& McDermott, P. (1998). Preschool version of the Social Skills Rating System: empirical analysis of its use with low-income children. Journal of School Psychology, 36, 199-214.

Ferreira, M. de C. T., \& Marturano, E. M. (2002). Ambiente familiar e os problemas do comportamento apresentados por crianças com baixo desempenho escolar. Psicologia: Reflexão e Crítica, 15 (1), 35-44.

Gerber, M. M., \& Semmel, M. I. (1984). Teacher as imperfect test: Reconceptualizing the referral process. Educational Psychologist, 19 (3), 137-148.

Gresham, F. M. (1996). Teachers as judges of social competence: A conditional probability analysis. School Psychology Review, 25 (1), 108-117.

Gresham, F. M., McMillan, D. L., \& Bocian, K. M. (1997). Teachers as "tests": Differential validity of teacher judgments in identifying students at-risk for learning difficulties. School Psychology Review, 26 (1), 47-60.

Gresham, F. M., Reschly, M., \& Carey, M. P. (1987). Teachers as "tests" classification accuracy and concurrent validation in the identification of learning disabled children. School Psychology Review, 16 (4), 543-553.

Hidalgo, C. G.C, \& Abarca, N. M. (1992). Communication interpessoal: Programa de entrenamiento en habilidades socials. Santiago: Ediciones Universidad Católica. 
Kaiser, A. P., \& Hester, P. P. (1997). Prevention of conduct disorder through early intervention: A social-communicative perspective. Behavioral Disorders, 22(3), 117-130.

McFall, R. M. (1982). A review and reformulation of the concept of social skills. Behavioral Assessment, 4, 1-33.

National Institute of Child Health and Human Development Early Child Care Research Network (2003). Social Functioning in First Grade: Associations with Earlier Home and Child Care Predictors and With Current Classroom Experiences. Child Development, 74, (6), 1639-1662.

Nunnally, J. C. (1970). Introduccion a la medicion psicologica. Buenos Aires: Editorial Paidos.

Pasquali, L. (1999). Testes referentes a construto: Teoria e modelo de construção. Em L. Pasquali (Ed.) Instrumentos psicológicos: Manual prático de elaboração (pp. 37-71). Brasília: LabPAM..

Pasquali, L. (1997). Psicometria: Teoria e aplicações. Brasília: Editora Universitária de Brasília.

Pasquali, L. (2000). Princípios de elaboração de escalas psicológicas. In C. Gorenstein, L. H. S. G. Andrade, \& A. W.
Zuardi (Eds.) Escalas de avaliação clínica em Psiquiatria e Psicofarmacologia (pp. 15-21). São Paulo: Lemos Editorial.

Pereira, J. C. R. (2004). Análise de dados qualitativos: Estratégias metodológicas para as ciências da saúde, humanas e sociais. $3^{\text {a }}$ ed., São Paulo: Editora da Universidade de São Paulo.

Rosales-Ruiz, J., \& Baer, D. M. (1997). Behavioral cusps: A developmental and pragmatic concept for behavior analysis. Journal of Applied Behavior Analysis, 30, 533-544.

Santos, P. L. dos (2002). Riscos e recursos em crianças com alto e baixo rendimento acadêmico: Um estudo comparativo. Unpublished Ph.D. Dissertation . Ribeirão Preto: Universidade de São Paulo.

Silva, A. T. B. (1997). Treinamento de habilidades sociais $e$ desenvolvimento de interações entre pais e filhos. Unpublished Bach. Dissertation. São Carlos: Universidade Federal de São Carlos.

Received April 11, 2007 Revision received September 12, 2008 Accepted September 30, 2008 
ANNEX 1

\section{Questionnaire of Sociall Skilled Responses - Teachers (QRSH-PR)}

\section{Interviewer's instructions:}

The interviewer informs the respondent of the characteristics of the instrument, instructing how it should be answered, according to the guidelines appearing in the Instructions item for the interview, as well as according to that requested in the report of information contained in the child characterization item. Then, the interviewer orally asks the questions (paraphrasing when necessary in order to guarantee comprehension), for example: «Does the child ask you questions?», if the respondent answers affirmatively, then they are asked how frequent such behavior occurs in order to verify if it «definitely applies», «applies somewhat», or «does not apply»; then the interviewer marks the response given by the respondent. The response «definitely applies» is attributed a score of 2; responses of «applies somewhat» are attributed a score of 1 ; and «does not apply» responses are attributed a score of 0 .

\section{Child's information:}

Child's name and age:

EMEI (school):

Teacher:

\section{Instructions for the interview subject:}

Below are a series of descriptions of behaviors frequently demonstrated by children. If the child definitely demonstrates the behavior described by the affirmation, answer «definitely applies». If the child exhibits the behavior, but in a lesser degree or less frequently, answer «somewhat applies». If, as far as you know, the child does not exhibit the behavior, answer «does not apply».

\begin{tabular}{|c|c|c|c|}
\hline BEHAVIORS & $\begin{array}{c}\text { Does not } \\
\text { apply }\end{array}$ & $\begin{array}{l}\text { Applies } \\
\text { a little }\end{array}$ & $\begin{array}{c}\text { Definitely } \\
\text { applies }\end{array}$ \\
\hline 1. Faz pedidos? & & & \\
\hline 2. Presta ajuda ao professor(a) e colegas? & & & \\
\hline 3. Faz amigos? & & & \\
\hline 4. Interage de forma não verbal com pessoas de sua convivência, por meio de sorrisos, gestos? & & & \\
\hline 5. Procura sua atenção? & & & \\
\hline 6. Faz perguntas? & & & \\
\hline 7. Cumprimenta as pessoas? & & & \\
\hline 8. Tem relações positivas com um ou mais colegas, mostrando capacidade para preocupar-se com eles? & & & \\
\hline 9. Expressa frustração e desagrado de forma adequada, sem prejudicar outras pessoas? & & & \\
\hline 10. Não é facilmente intimidado por crianças violentas ou agressivas? & & & \\
\hline 11. Brinca com colegas? & & & \\
\hline 12. Faz elogios? & & & \\
\hline 13. Expressa desejos e preferências, de forma adequada? & & & \\
\hline 14. Toma iniciativas? & & & \\
\hline 15. Expressa carinhos? & & & \\
\hline 16. Comunica-se com as pessoas de forma positiva? & & & \\
\hline 17. Expressa seus direitos e necessidades de forma apropriada? & & & \\
\hline 18. Usualmente está de bom humor? & & & \\
\hline 19. Expressa opiniões? & & & \\
\hline 20. Negocia e convence outras pessoas de seu ponto de vista? & & & \\
\hline 21. Participa de grupos de jogos e trabalhos em sala de aula? & & & \\
\hline 22. Participa de temas de discussão, dando contribuições relevantes? & & & \\
\hline 23. Toma a palavra facilmente? & & & \\
\hline 24. Mostra interesse pelos outros, muda de opinião e aceita informação de outros de forma adequada? & & & \\
\hline
\end{tabular}

